•编者按・

\title{
重新审视野生动物与公共健康的关系
}

\author{
吕 植 ${ }^{*}$ \\ (北京大学生命科学学院, 北京 100871)
}

\section{Reassess wildlife conservation in the context of public health}

Zhi Lü*

School of Life Sciences, Peking University, Beijing 100871

新冠肺炎自2019年底暴发至今已经历时半年 之久, 仍在全球蔓延, 每日新增感染人数居高不 下。作为一个重大公共卫生事件, 此次新冠肺炎的 流行给人类健康带来无限伤痛, 使全球的经济、贸 易、外交、社会心理等各个层面受到前所未有的巨 大影响。

尽管新冠病毒的来源和传播途径在科学上尚 未确认, 但目前为止大多数研究都认为新冠病毒来 自自然界, 由自然宿主(如被怀疑的蝙蝠等野生动 物)传播到尚不明确的中间宿主, 历经突变, 然后感 染了人类。统计表明, 近些年来世界各地出现的新 发传染病, 例如亨德拉、尼帕病毒, H7N9禽流感、 埃博拉、SARS、中东呼吸综合征等等, 都和动物有 关。这些病毒存在于自然界, 与宿主野生动物长期 协同演化, 已经达成某种平衡。然而, 人类对野生 动物的非法贸易和消费, 或者对野生动物栖息地的 开发, 有可能使得这些病毒与人类的接触大幅增加, 给病毒从野生动物传播到人类创造了条件, 危及公 共卫生安全。加之全球化的趋势、交通的便利和人 口的流动, 使得流行病暴发的几率大大增加。

生物多样性与公共卫生安全之间的联系从未 像今天这样紧密, 并让人们有如此深刻的切肤之 痛。为此, 全国人民代表大会常务委员会在 2020 年 2月24日做出决定, 全面禁止和惩治非法野生动物 交易行为, 革除滥食野生动物的陃习, 维护生物安 全和生态安全, 有效防范重大公共卫生风险, 切实 保障人民群众生命健康安全, 加强生态文明建设, 促进人与自然和谐共生。
在此背景下, 《生物多样性》周欣编委提议组 织一期专刊, 探讨生物多样性与人类大规模传染病 之间的关系, 比如: 从公共健康、生物多样性保护 和相关产业发展等不同角度考虑如何禁用野生动 物, 如何长期积累病毒和宿主等基础生物学数据, 如何应用系统学和基因组学确定病毒来源等等。提 议得到马克平主编大力支持, 以及华方圆、蒋志刚、 李涁涁、肖治术、朱朝东等编委的积极响应, 大家 还认为数据开放共享、疫病溯源以及病毒分类、变 异、进化等问题都值得深入探讨。随后, 我们分别 进行约稿或亲自撰稿, 就相关学科领域的研究、调 查进行快速整理, 形成文字, 在此结集发表, 以期 为读者和公众提供野生动物与公众健康以及与之 相关的生物多样性方面的知识、观点和研究背景, 也希望为决策者提供科学依据。遗憾的是, 有的约 稿没能按预定时间完成, 未收入专辑, 我们后面会 尽快安排发表。

本专辑收录的论文涉及领域非常广泛。

从技术上, 韩本风等(2020) 以 SARS-CoV-2 为 例, 总结了基因组学技术在病毒鉴定与溯源上的应 用, 并针对当前动物病毒库完整性低的现状, 对构 建野生和家养动物携带病毒的关联数据库的可行 性提出依据与建议。王然和乔慧捷(2020)比较了疫 病传播中常用的生态位建模方法的优势与不足, 指 出SARS-CoV-2因人传人的特点, 不宜用生态位模 型对其潜在传播范围进行预测, 使用生态位模型时 需考虑建模对象是否满足生态学假设, 不可滥用。

曾岩等(2020)首次从科学和保护管理的角度对 
“野生动物”的概念在中文语境下进行了梳理和澄清, 提出“野生动物”与“驯化动物”之间渐进、多层次的二 维框架, 并对我国《野生动物保护法》中适用的野生 动物概念给出建议。蒋志刚等(2020)强调了我国的濒 危物种红色名录即濒危物种国别研究对中国的生物 多样性保护和相关法律制定和修订的意义。

肖治术等(2020)总结了我国24种重要兽类疫病 的监管情况, 对我国重要陆生兽类疫源疫病发生的 新情况和新特点进行了全面分析, 指出我国重要野 生动物疫源疫病管理呈现多部门、多层监管的局面; 存在非法猎杀、非法交易、违法违规养殖、滥食野 生动物陃习、检疫环节失察等安全风险; 而对新发 再发传染病的认知不足, 加之气候变化和自然灾害 频发进一步使得从源头做好疫病防控面临困难, 需 要加强基础研究和监管来积极防范陆生野生动物 疫病疫情。姬云瑞等(2020)对网络交易平台上外来 宠物贸易的种类、规模、价格进行了调查。共记录 到外来宠物111种, 其中不乏IUCN红色名录中的受 威胁物种和CITES公约附录的物种, 说明对于网络 平台动物贸易进行监管的重要性。此外, 朱俊华等 (2020)对被利用严重的古老海洋节肢动物中华鲎 (Tachypleus tridentatus)的状况和威胁及保护需求提 出了观点。

梁智健等(2020)从社会学、心理学、行为科学 等多学科的视角分析和理解我国野生动物消费的 需求动因: 功能性、社会性和体验性等非生活必需 性需求凸显, 提出了做出改变的可能和挑战。而史 湘莹等(2020)则通过74,040份网络问卷调查, 了解 了疫情暴发后以城镇居民为主的公众对于野生动 物消费和贸易的意愿, 结果显示, 绝大多数被调查
者对全面禁止野味消费持赞成态度，且多数现有野 生动物消费群体在疫情后倾向于停止消费。这一调 查表明，一些不良的行为习惯在重大灾害面前出现 了改变的契机，全国人民代表大会常务委员会禁食 野生动物的决定在受高等教育者和城镇居民中有 良好的公众基础。

吕忠梅等(2020)讨论了现行《野生动物保护法》 保护范围较窄、监管体制不顺、执法标准不科学、 法律制度不完善等问题，建议《中华人民共和国野 生动物保护法》的修订要在完善立法目的、合理界 定保护范围、健全“黑白”名单制度和许可证制度、 优化野生动物保护监管体制、完善激励机制和法律 责任制度等方面认真加以研究, 为促进环境治理体 系和治理能力现代化 “立良法”。李彬涁(2020)介绍 了 One Health的理念框架, 即通过交叉学科的研究、 行动和治理, 来推动包括人、所有其他动物及环境 的整体健康。One Health的理念在国际上被广泛接 纳, 《生物多样性公约》也对其进行推广。中国应 将预警与干预措施前移，减少疾病暴发带来的社会 经济成本。

此次疫情再次提醒我们, 人类需要反思我们与 其他生命的关系, 重建对自然的敬畏, 维护人与自 然之间、人与野生动物及其病原体之间的生态平衡, 最终受益的是人类自身的生存安全和长久利益。这 也是我们出版这本专辑的初衷。

文中引用的文献均来自本期文章, 参见附录 (http://www.biodiversity-science.net/fileup/PDF/2020 288-1.pdf)。

(责任编辑：周玉荣) 
吕植. 重新审视野生动物与公共健康的关系. 生物多样性, 2020, 28(5): 539-540. http://www.biodiversityscience.net/CN/10.17520/biods.2020288

\section{参考文献}

Han BF, Zhou X, Zhang X (2020) Verification of virus identity and host association using genomics technologies. Biodiversity Science, 28, 587-595. (in Chinese with English abstract) [韩本凤，周欣，张雪（2020）基因组学技术在病 毒鉴定与宿主溯源中的应用. 生物多样性, 28, 587-595.]

Ji YR, Li Y, Liu F, Li DQ (2020) Assessment of current trade of exotic pets on the internet in China . Biodiversity Science, 28, 644-650. (in Chinese with English abstract) [姬云瑞, 李叶, 刘芳, 李迪强 (2020) 我国网络平台外来宠物贸易调查. 生物多样性, 28, 644-650.]

Jiang ZG, Jiang JP, Wang YZ, Zhang E, Zhang YY, Cai B (2020) Significance of country red lists of endangered species for biodiversity conservation. Biodiversity Science, 28, 558565. (in Chinese with English abstract) [蒋志刚, 江建平, 王 跃招, 张鹗, 张雁云, 蔡波 (2020) 国家濒危物种红色名 录的生物多样性保护意义. 生物多样性, 28, 558-565.]

Li BBV (2020) Creating synergy between biodiversity conservation and human health-One Health. Biodiversity Science, 28, 596-605. (in Chinese with English abstract) [李 涁涁 (2020) 推进生物多样性保护与人类健康的共同发 展—One Health. 生物多样性, 28, 596-605.]

Liang ZJ, Hu JB, Hu SF, Zhao JJ, Zhou KW, Jiao YB, Huang C, He X, Wan AKY, Li LS, Hua FY, Li TM (2020) Understanding and changing wildlife consumption behavior from a multidisciplinary perspective. Biodiversity Science, 28, 606-620. (in Chinese with English abstract) [梁智健, 胡 佳贝, 胡思帆, 赵晶晶, 周凯文, 焦运波, 黄程, 何霞, 温 嘉恩, 李立姝, 华方圆, 李添明 (2020) 多学科视角下的 野生动物消费需求和行为研究进展. 生物多样性, 28 , 606-620.]

Lü ZM, Chen ZL (2020) Revision of the Law of the People's Republic of China on the Protection of Wildlife: Background, issues and suggestions. Biodiversity Science, 28, 550-557. (in Chinese with English abstract) [吕忠梅, 陈真亮 (2020)
野生动物保护法》再修订: 背景、争点与建议. 生物多样 性, 28, 550-557.]

Shi XY, Zhang XC, Xiao LY, Li BBV, Liu JM, Yang FY, Zhao X, Cheng C, Lü Z (2020) Public perception of wildlife consumption and trade during the COVID-19 outbreak. Biodiversity Science, 28, 630-643. (in Chinese with English abstract) [史湘荣, 张晓川, 肖凌云, 李涁涁, 刘金梅, 杨 方义, 赵翔, 程琛, 吕植 (2020) 新冠肺炎时期公众对野 生动物消费和贸易意愿的调查. 生物多样性, 28, 630 643.]

Wang R, Qiao HJ (2020) Matters needing attention about invoking ecological niche model in epidemiology. Biodiversity Science, 28, 579-586. (in Chinese with English abstract) [王然, 乔慧捷 (2020) 生态位模型在流行病学中 的应用. 生物多样性, 28, 579-586.]

Xiao ZS, Zhang LB, Xu L, Zhou QH, Meng XX, Yan C, Chang G (2020) Problems and countermeasures in the surveillance and research of wildlife epidemics based on mammals in China. Biodiversity Science, 28, 566-578. (in Chinese with English abstract) [肖治术, 张礼标, 许磊, 周岐海, 孟秀 祥, 严川, 常罡 (2020) 以兽类为例探讨我国陆生野生动 物疫病监管中面临的问题与对策. 生物多样性, 28, 566578.]

Zeng Y, Ping XG, Wei FW (2020) A conceptual framework and definition for the term "wild animal". Biodiversity Science, 28, 541-549. (in Chinese with English abstract) [曾岩，平晓 鸽, 魏辅文 (2020) “野生动物”的概念框架和术语定义. 生物多样性, 28, 541-549.]

Zhu JH, Wu Z, Feng BB, Deng SS, Zhen WQ, Liao YY, Xie XY, Kwan KY (2020) Global conservation of Tachypleus tridentatus: Present status and recommendations. Biodiversity Science, 28, 621-629. (in Chinese with English abstract) [朱俊华，吴宙，冯炳斌，邓帅帅，甄文全，廖永 岩, 颉晓勇, Kit Yue Kwan (2020) 全球中华鲎资源保护现 状及对策建议. 生物多样性, 28, 621-629.] 